\title{
Research Square \\ Exploration of workplace violence among nurses at a selected University Teaching Hospital in Rwanda
}

Gilbert Banamwana ( $\sim$ banagilberto@yahoo.fr)

Research article

Keywords: Workplace, workplace violence, nurses

Posted Date: December 3rd, 2020

DOI: https://doi.org/10.21203/rs.2.18002/v2

License: (c) (1) This work is licensed under a Creative Commons Attribution 4.0 International License.

Read Full License 


\section{BMC Nursing \\ Exploration of Workplace Violence Experience among Nurses at Selected University Teaching Hospital in Rwanda \\ --Manuscript Draft--}

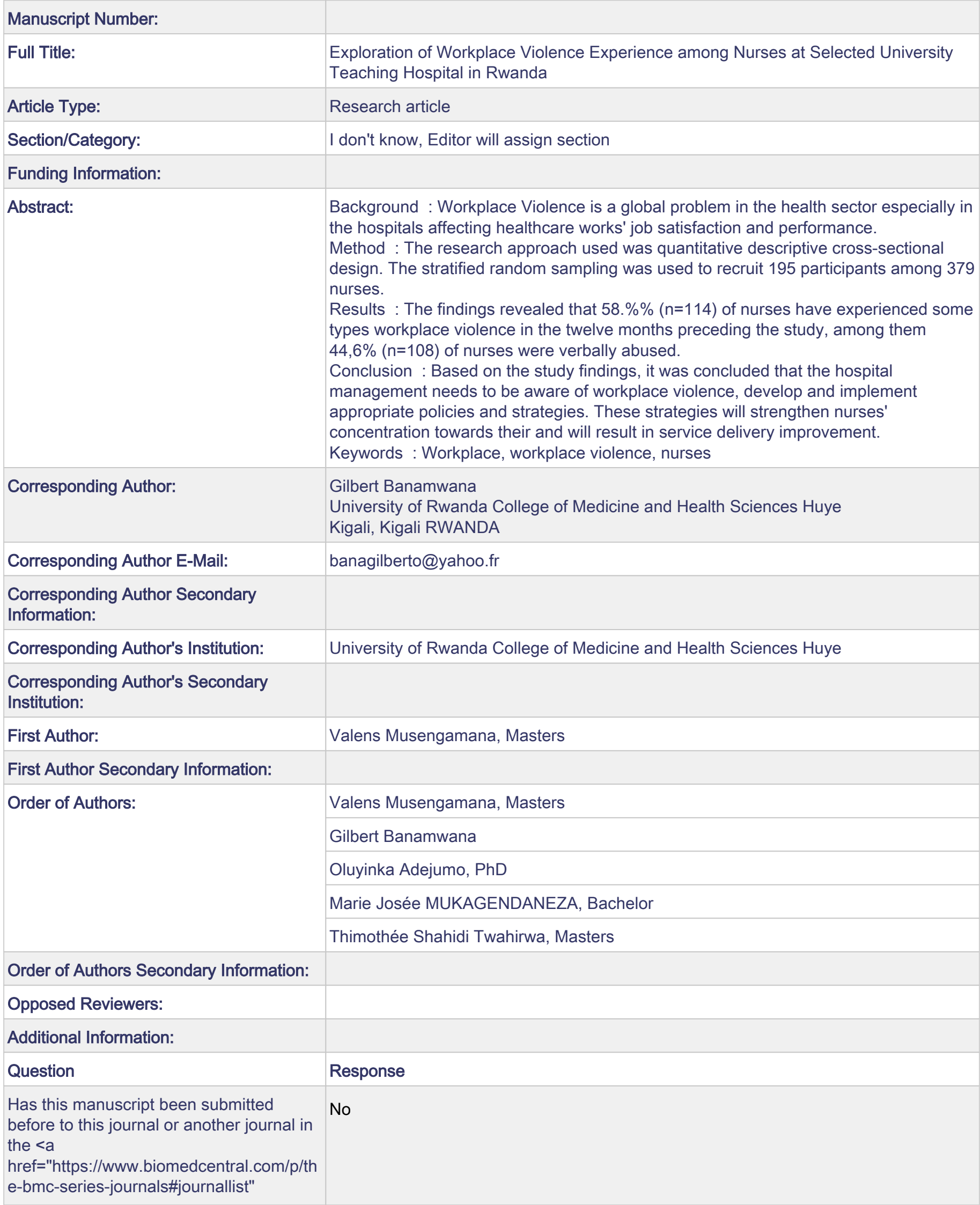


target="_blank" $>$ BMC series $<$ a $>$ ? 
Click here to view linked References

\section{EXPLORATION OF WORKPLACE}

\section{VIOLENCE EXPERIENCE AMONG}

\section{NURSES AT A SELECTED UNIVERSITY} TEACHING HOSPITAL IN RWANDA

\section{MUSENGAMANA Valens}

Student Registration Number: 216338034

Supervisor: Prof. OluyinkaAdejumo

CO-Supervisor: Mr Gilbert Banamwana

ValensMUSENGAMANA, RN, BScN, MScN @

mvalens2000@yahoo.fr

Student at University of RWANDA

College of Medicine and Health Sciences

School of Nursing and Midwifery

P.O Box: 3286, Kigali, Rwanda

Prof OluyinkaAdejumo, DLitt et Phil, RN, RPN, RNE

Oa18@nyu.edu

Training Specialist in the HRH Rwanda Program

New York University College of Nursing, NY 10010

c/o Office of the Dean, School of Nursing and Midwifery,

College of Medicine and Health Sciences, University of Rwanda,

Remera Campus. Kigali. RWANDA.

Gilbert Banamwana, RN, BScN, $\mathrm{MScN}$

banagilberto@yahoo.fr

Assistant Lecturer at University of RWANDA

College of Medicine and Health Sciences

School of Nursing and Midwifery

P.O Box: 3286, Kigali, Rwanda

Marie Josée MUKAGENDANEZA,RN, BScN, MScN

mujosee@gmail.com

Head of Infection Prevention and Control Unit

Kigali University Teaching Hospital

P.O Box: 655, Kigali, Rwanda 
ThimothéeShahidiTwahirwa, RN, BScN, MScN

shahiditim@gmail.com

Health Services Administration Specialist,

Director of Quality Managementt at Kigali University Teaching Hospital.

A dissertation submitted in partial fulfilment of the requirements for the degree of Master of Science Nursing (Education, Leadership and Management Track) in University of Rwanda 


\title{
Exploration of workplace violence experience among nurses at a selected University Teaching Hospital in Rwanda
}

ValensMusengamana ${ }^{1 *}, \quad$ Prof.Oluyinka JoséeMukagendaneza ${ }^{4}$, ThimothéeShahidi Twahirwa ${ }^{5}$.

Marie

\begin{abstract}
Background: Workplace violence is a global problem in the health sector especially in the hospitals affecting healthcare works' job satisfaction and performance. Workplace violence is present in different forms associated with various factors and the nurses are the most affected. The aim of this study was to explore workplace violence experience among nurses working at a selected University Teaching Hospital in Rwanda.

Method: Theresearch approach usedwasquantitative descriptive cross-sectional design. The stratified random sampling was used to recruit 195 participants among 379 nurses. The data was collected using a structured, validated, and self-administered questionnaire that was adapted from the International Labor Organization, International Council of Nurses, World Health Organization and Public Services International. Descriptive statistics were used for analyzing frequencies and percentages. Chi-square test was used for evaluating the association between variables.

Results: The findings revealed that $(58.5 \%, n=114)$ of nurses have experienced some types of WPV in the twelve months preceding the study, among them $(44.6 \%, n=108)$ of nurses were verbally abused. The nurses providing emergency care, the nurses working at the emergency department and nurses working with vulnerable patients like HIV/AIDS patients were associated with workplace violence Chisquare(1, $n=195), P=<0.001)$. The psychological problemshas been found as the first consequences of workplace violence.

Conclusions: Based on the study findings, it was concluded that the hospital management needs to be aware ofworkplace violence, develop and implement appropriate policies and strategies. These strategies will strengthen nurses' concentration towards their and will resulting in service delivery improvement.
\end{abstract}

Keywords: Workplacel workplace violencel Nurses

*Correspondence: mvalens2000@yahoo.fr

1 University of RWANDA, College of Medicine and Health Sciences, School of Nursing and Midwifery and Risk management officer at Kigali University Teaching Hospital

Full list of author information is available at the end of the article 


\section{Background}

Workplace violence (WPV) in the healthcare system is a worldwide work concern (1).World Health Organization (WHO) defined WPV as an incident where employees are abused, threatened, or assaulted in conditions linked to their work. It can happen at work, while travelling to and after work. The consequencesof WPV include the physical and psychological negatives effects. The phenomenon affects all types of healthcare workers (2),(3). In 2013, the Bureau of Labor Statistics (BLS) in the United States of America (USA) testified that each year WPV attacks about 25,000and most of them were in healthcare settings and welfare service and its consequencesare high compared to the other sector of employees (4).

The most common causes of WPV are overcrowding of patients and nurses' workload, nursing staff shortages, the patients suffering from dementia or Alzheimer's illness (5). Long waiting time, lack of prevention measures, unmet patients and family needs are also the causes of WPV (1). The most highlighted consequences of WPV are injuries (6), reduction of work performance (7), the attainment of institutions productions (3), leaving job (8), psychological distresses(9).

Some interventions to address the WPV include training, restricted access, overcrowding reduction, exit strategies(8), having laws, occupational health/safety legislation and reporting incidents to the relevant authority (10).

The existing study carried out in Rwandan district hospitals was exploring the WPV in the context of gender discrimination but did not delve into WPV among nurses working in referral hospitals (14).Therefore, considering the paucity of data related to WPV in Rwandan healthcaresettings, this study aimed to explore WPV experience among nurses at a selected University Teaching Hospital in Rwanda.

\section{Methods}

The study used a quantitative descriptive crosssectional design to explore WPV experience among 379 nurses at University Teaching Hospital of Kigali.A Stratified systematic random sampling was used to obtain 195 participants.Yamane's formula was used to calculate sample size.Data was collected in March 2019 by recalling the WPV experience happened in the twelve months prior to the study.

The self-administered questionnaire used was adopted from the instrument elaborated by the International Labor Organization (ILO), International Council of Nurses (ICN), World Health Organization (WHO) and Public Services International (PSI)(11). The permission to use the instrument was granted from ILO Library by email correspondence and was adapted to remain with the questions measuring objectives of the study. The reliability was .834 Cronbach's alpha.

Data was analyzed by using Statistical Package for the Social Sciences (SPSS) version 21.Descriptive statistics were used for analyzing frequencies and percentages. Chi-square test was used to assess the association between factors (age groups, sex, working experience, types of patients, sex of patients, working in specific specialties, working with vulnerable patients, working alone) and WPV.

\section{Results}

\section{Characteristics of the participants}

All participants responded to the questionnaires. The majority of participants were females $84.6 \%$ than males $15.4 \%$. The ages ranged from 25 to 64 years,most participants were in age group of 30-39 (50.3\%). Almost (83.6\%) of respondents were married. Most respondents had more than 6 years of experience $(85.1 \%)$ (table1). 
Table 1: Gender, age, marital status and nursing work experience of the study participants

\begin{tabular}{|l|l|l|l|}
\hline Variables & Categories & Frequency & Percent \\
\hline \multirow{4}{*}{ Gender } & Female & 165 & 84.6 \\
\cline { 2 - 4 } & Male & 30 & 15.4 \\
\hline \multirow{5}{*}{ Age } & $25-29$ years & 12 & 6.2 \\
\cline { 2 - 4 } & $30-34$ years & 46 & 23.6 \\
\cline { 2 - 4 } & $35-39$ years & 52 & 26.7 \\
\cline { 2 - 4 } & $40-44$ years & 47 & 24.1 \\
\cline { 2 - 4 } & $45-49$ years & 26 & 13.3 \\
\cline { 2 - 4 } & $50-54$ years & 6 & 3.1 \\
\cline { 2 - 4 } & $55-59$ years & 4 & 2.1 \\
\cline { 2 - 4 } & 60 -64 years & 2 & 1.0 \\
\hline \multirow{5}{*}{ Marital status } & Lingle & 25 & 12.8 \\
\cline { 2 - 4 } & Married & 163 & 83.6 \\
\cline { 2 - 4 } & Separated or Divorced & 3 & 1.5 \\
\cline { 2 - 4 } & Widow or Widower & 3 & 1.5 \\
\hline \multirow{5}{*}{} & $1-5$ Years & 29 & 14.9 \\
\cline { 2 - 4 } & $6-10$ Years & 62 & 31.8 \\
\cline { 2 - 4 } & $11-15$ Years & 40 & 20.5 \\
\cline { 2 - 4 } & $16-20$ years & 38 & 13.3 \\
\cline { 2 - 4 } & Over 20 years & 19.5 \\
\hline
\end{tabular}

\section{Types of WPV in the last 12 months}

The findings showed that $58.5 \%$ of nurses have experienced at least one type of WPV.Among them $44.6 \%$ were verbally abused, $15.4 \%$ were bullied/mobbed, (6.7\%) have experienced physical violence and $(2.1 \%)$, have experienced sexual harassment (table 2).
Table 2: Types of WPV experienced in the last 12 months

\begin{tabular}{|c|c|c|c|}
\hline Variables & Categories & Frequency & y Percent \\
\hline \multirow{2}{*}{$\begin{array}{l}\text { Some types of } \\
\text { WPV }\end{array}$} & No & 81 & 41.5 \\
\hline & Yes & 114 & 58.5 \\
\hline \multirow{4}{*}{ Physical violence } & No & 182 & 93.3 \\
\hline & Yes & 13 & 6.7 \\
\hline & $\begin{array}{l}\text { Physical violence } \\
\text { without a weapon }\end{array}$ & 12 & 6.2 \\
\hline & $\begin{array}{l}\text { Physical violence with } \\
\text { a weapon }\end{array}$ & 1 & .5 \\
\hline \multirow{2}{*}{ Verbal abuse } & No & 87 & 44.6 \\
\hline & Yes & 108 & 55.4 \\
\hline \multirow{2}{*}{ Bullying/Mobbing } & No & 165 & 84.6 \\
\hline & Yes & 30 & 15.4 \\
\hline \multirow{2}{*}{$\begin{array}{l}\text { Sexual } \\
\text { harassment }\end{array}$} & No & 191 & 97.9 \\
\hline & Yes & 4 & 2.1 \\
\hline
\end{tabular}

\section{Factors associated with WPV}

A Chi-square for independence showed a significant association between working in specific specialties and WPV, $\mathrm{Chi}^{2}(1, \mathrm{n}=195), \mathrm{P}=<0.001$, with a high WPV to the nurses working in emergency care specialty (mean=1.50), and HIV/AIDS patients (mean=1.11). Furthermore, the results revealed a highlyassociation between WPV at accident and emergency department $($ mean $=1.68)($ Table3 $)$ 
Table 3: Factors associated with WPV

\begin{tabular}{|c|c|c|c|c|c|c|}
\hline Variables & Categories & Mean & $N$ & df & Value & $\begin{array}{l}\text { P- } \\
\text { Value }\end{array}$ \\
\hline \multirow[t]{2}{*}{ Gender } & Female & 0.79 & 165 & \multirow[t]{2}{*}{3} & \multirow[t]{2}{*}{0.38} & \multirow[t]{2}{*}{0.287} \\
\hline & Male & 0.87 & 30 & & & \\
\hline \multirow[t]{8}{*}{ Age } & $25-29$ years & 0.75 & 12 & \multirow[t]{8}{*}{21} & \multirow[t]{8}{*}{27.91} & \multirow[t]{8}{*}{0.143} \\
\hline & $30-34$ years & 0.74 & 46 & & & \\
\hline & 35-39 years & 1.06 & 52 & & & \\
\hline & 40-44years & 0.70 & 47 & & & \\
\hline & $45-49$ years & 0.80 & 26 & & & \\
\hline & $50-54$ years & 0.17 & 6 & & & \\
\hline & 55-59 years & 0.25 & 4 & & & \\
\hline & $60-64$ years & 1.00 & 2 & & & \\
\hline \multirow[t]{4}{*}{ Marital status } & Single & 0.80 & 25 & \multirow[t]{4}{*}{12} & \multirow[t]{4}{*}{3.55} & \multirow[t]{4}{*}{0.997} \\
\hline & Married & 0.81 & 163 & & & \\
\hline & $\begin{array}{ll}\text { Living with } \\
\text { partner }\end{array}$ & 0.00 & 1 & & & \\
\hline & $\begin{array}{l}\text { Separated } \\
\text { Divorced }\end{array}$ & 1.00 & 3 & & & \\
\hline \multirow{5}{*}{\begin{tabular}{|l|} 
Nursing work \\
experience
\end{tabular}} & $1-5$ Years & 0.73 & 29 & \multirow[t]{5}{*}{12} & \multirow[t]{5}{*}{12.75} & \multirow[t]{5}{*}{0.387} \\
\hline & 6-10 Years & 0.90 & 62 & & & \\
\hline & 11-15 Years & 0.80 & 40 & & & \\
\hline & $16-20$ years & 0.88 & 26 & & & \\
\hline & Over 20 years & 0.63 & 38 & & & \\
\hline \multirow{3}{*}{$\begin{array}{l}\text { The category } \\
\text { of patients/ } \\
\text { clients }\end{array}$} & Newborns & 0.70 & 10 & \multirow[t]{3}{*}{6} & \multirow[t]{3}{*}{5.26} & \multirow[t]{3}{*}{0.511} \\
\hline & Children & 0.61 & 33 & & & \\
\hline & Adults & 0.85 & 152 & & & \\
\hline \multirow{3}{*}{$\begin{array}{l}\text { The sex o } \\
\text { patients }\end{array}$} & Female & 1.03 & 35 & \multirow[t]{3}{*}{6} & \multirow[t]{3}{*}{7.49} & \multirow[t]{3}{*}{0.278} \\
\hline & Male & 0.71 & 7 & & & \\
\hline & $\begin{array}{l}\text { Male } \\
\text { female }\end{array}$ & 0.75 & 153 & & & \\
\hline \multirow[t]{5}{*}{ Specialties } & $\begin{array}{l}\text { Physical } \\
\text { disabled }\end{array}$ & 0.38 & 42 & \multirow{5}{*}{18} & \multirow[t]{5}{*}{58.96} & \multirow[t]{5}{*}{$\begin{array}{l}<0.00 \\
1\end{array}$} \\
\hline & $\begin{array}{l}\text { Mother/child } \\
\text { care }\end{array}$ & 0.79 & 67 & & & \\
\hline & Terminally ill & 0.73 & 26 & & & \\
\hline & HIV/AIDS & 1.11 & 6 & & & \\
\hline & $\begin{array}{l}\text { Emergency } \\
\text { care }\end{array}$ & 1.50 & 24 & & & \\
\hline
\end{tabular}

\begin{tabular}{|c|c|c|c|c|c|c|}
\hline & $\begin{array}{l}\text { Chronic dise } \\
\text { care }\end{array}$ & 0.85 & 20 & & & \\
\hline & Others & 0.80 & 10 & & & \\
\hline Departments/S & OPD & 1.00 & 16 & 21 & 78.9 & $<0.00$ \\
\hline ervices & $\begin{array}{l}\text { Internal } \\
\text { medicine }\end{array}$ & 1.03 & 29 & & & 1 \\
\hline & surgical & 0.34 & 35 & & & \\
\hline & Maternity & 0.96 & 31 & & & \\
\hline & Pediatrics & 0.63 & 36 & & & \\
\hline & Emergency & 1.68 & 19 & & & \\
\hline & Theater & 0.53 & 15 & & & \\
\hline & Critical care & 0.35 & 14 & & & \\
\hline The number of & None & 0.90 & 10 & 12 & 17.77 & 0.123 \\
\hline staff present & $1-5$ & 0.84 & 126 & & & \\
\hline & $6-10$ & 0.57 & 33 & & & \\
\hline & $11-15$ & 1.00 & 16 & & & \\
\hline & Over 15 & 0.60 & 10 & & & \\
\hline
\end{tabular}

\section{Consequences of WPV}

The most consequences of WPV experience were psychological problems like avoiding thinking about it or talking about the attack or avoiding having feelings interrelated to it (43.6\%).The repeated, worrying memories, thoughts, or images of the attack was at rate of $35.9 \%$, being super-alert or watchful and on guard $11.8 \%$, feeling like everything you did was an effort $11.3 \%$. Thinking of leaving the job $10.8 \%$, reduction of work performance $11.8 \%$ and nurses felt ashamed or guilty after being violated $9.7 \%$. One $(0.5 \%)$ nurse has been injured as results of the violence (table4). 
Table 4: Consequences of WPV

\begin{tabular}{|l|l|l|}
\hline Variables & Frequency & Percent \\
\hline $\begin{array}{l}\text { Repeated, disturbing memories, } \\
\text { thoughts, or images of the attack }\end{array}$ & 35.9 \\
\hline $\begin{array}{l}\text { Avoiding thinking about or talking about } \\
\text { the attack or avoiding having feelings } \\
\text { related to it }\end{array}$ & 43.6 \\
\hline $\begin{array}{l}\text { Being super-alert or watchful and on } \\
\text { guard }\end{array}$ & 23 & 11.8 \\
\hline $\begin{array}{l}\text { Feeling like everything you did was an } \\
\text { effort }\end{array}$ & 22 & 11.3 \\
\hline Reduction of work performance & 21 & 10.8 \\
\hline Thinking of leaving the job & 27 & 13.8 \\
\hline Felt ashamed or guilty & 19 & 9.7 \\
\hline Injured as a result of the violence & 1 & 0.5 \\
\hline
\end{tabular}

\section{Discussion}

\section{Types of WPV in the last 12 months}

The study indicated that $(58.5 \%)$ of nurses have experienced at least one type of WPV. However, the frequency is less compared to the studies conducted in Gambia (62.1\%) (12), China (about 66\%) (13), in Malawi (70.54\%) (14) and high compared to the studies conducted in Italy (45\%) (9) and in Saudi Arabia (36\%), (7).

Concerning the types of WPV, (6.7\%) of nurses experienced physical violence. This rate is low comparedto the studies conducted in some countries; in North West of Ethiopia (60.2\%) (3), in Democratic Republic of Congo (53.6\%) (15), in Texas State (USA) (49.8\%) (8), in Malawi (22\%) (14). In the South Ethiopia, physical violence was for $18 \%$, (2) in Gambia (17.2\%) (12), in China (around 12\%) (13), in Lebanon $(10 \%)(16)$.

The findings of the present study revealed that $44.6 \%$ of nurses were verbally abused. These resultsare low compared to thestudies conducted in different countries, in Malawi (95\%) (14), in the South of Ethiopia (90\%) (2) in China (65\%) (13) in Lebanon (62\%) (16), in Gambia (59.8\%) (12), in the Democratic Republic of Congo (59.0\%) (15) and in Ghana (52.7\%) (17).

The results showed that $15.4 \%$ of nurses were bullied/mobbed. Thesefindingsare also low comparedto the studies conducted in different countries, in Malawi (73\%) (14), in the North West of Ethiopia (39.8\%) (3). Lastly, the findings showed that $2.1 \%$ of nurses have experienced sexual harassment, this frequency is very low compared to the studies conducted in the Democratic Republic of Congo (63.3\%) (15), in Texas State (USA) (46\%), (8) in Malawi (16\%) (14), in South of Ethiopia (13\%) (2), in Ghana (12, 2\%) (17), and in Gambia (10\%) (12).

\section{Factors associated with WPV}

The study revealed a significant association between working in a specific specialties and WPV, $\mathrm{Chi}^{2}(1$, $\mathrm{n}=195), \mathrm{P}=<0.001$, with a high WPV to the nurses working in emergency care specialty (mean $=1.50)$, and HIV/AIDS (mean=1.11), an association between working in accident and emergency department (mean=1.68). The results of this study are similar to those found inItaly where working at emergency department were the most associated with WPV (9) and in South Ethiopia (2). Therefore, working with suffering persons generates WPV becausesuffering persons are frustrated and irritated due to their illness and pain. Violence is common amongst workers in contact with them and it is frequently reflected an unavoidable part of the occupation (18). This is the case of the nurses giving emergency care or working at accident and emergency and for nurses working with the patients with HIV/AIDS. 


\section{Consequences of WPV}

Theconsequences of WPV among nurseshighlighted in the study were psychological distresses; like avoiding thinking about or talking about the attack or avoiding having feelings related to it $43.6 \%$, repeated, disturbing memories, thoughts, or images of the attack at rate of $35.9 \%$, being super-alert or watchful and on guard $11.8 \%$, feeling like everything you did was an effort $11.3 \%$, reduction of work performance $11.8 \%$ and nurses felt ashamed or guilty after being violated 9.7\%.These findings aresupported by previous studies conducted in Italy where psychological distresseswere (73\%) (9).Therefore, our findings are supported by studies conducted in Ghana where complains of repeated disturbed memories and feelings or images of the abuse were $33.8 \%(17)$. The study conducted in Saudi Arabia indicated that the decreasing in job productivity was $(31.1 \%)(7)$,in Palestine psychological distresses $(9.3 \%)$ as well as feelings of guilt (1.3\%) (1), in Lebanon nurses had high levels of emotional exhaustion and depersonalization (16).

The studydiscoveredthat $(10.8 \%)$ of nurses think of leaving their job. This frequency is low compared to the studies conducted in Lebanon where (31.7\%) thought leaving their nursing job (16), also in Palestine (1), in North of Ethiopia the reduction of institutions productions(3).

\section{Limitation of the study}

The study was steered in one of the University Teaching Hospital in the entire country, limited to one category of healthcare workers (nurses) and used quantitative approach only.The researchers suggested to be completed by qualitative approach. Furthermore, the study was used a prospective self-reporting approach in data gathering, by recalling events in the last twelve months prior to study which might have possible biases.

\section{Conclusion}

A significant WPV is present among nurses working at CHUK under their all types. Working at the emergency department and working with vulnerable patients like HIV/AIDS patients were highly associated with WPV. Psychological distresses are the most consequences. The development and implementation of policies and strategies at hospital level and at national level are needed. These strategies could enable healthcare workers to be focused on their job resulting in improvement of service delivery.

\section{List of abbreviations}

BLS: The Bureau of Labor Statistics; HIV/AIDS: Human Immunosuppressed Virus/Acquired ImmunoDeficiency Syndrome;IRB: Institutional Review Board; ILO: International Labor Organization; ICN: International Council of Nurses; PSI: Public Services International; OPD: Out Patient Department; SPSS: Statistical Package for the Social Sciences; USA: United States of America; CHUK: Centre HospitalierUniversitaire de Kigali; WHO:World Health Organization; WPV: Workplace violence.

\section{Declarations}

Ethics approval and consent to participate: The ethical clearance for data collection was acquired from the Institutional Review Board (IRB) of the University of Rwanda and the permission to collect data was obtained from CHUK ethics and research committee. The explanation related to the aim of the study was given, privacy and voluntary participation were respected and the consent forms were signed.

Consent for publication: Not applicable.

Availability of data and materials: All relevant data were within the manuscript.

Competing interests: The authors declare that they have no competing interests. 
Funding: The authors declare that there was no funding used in this study.

Authors' contribution: MV conceptualized the study design, data collection, pilot tested, collected, entered and analyzed the data, wrote the manuscript.

AO supervised and approved all the process of the study including manuscript.

BG co-supervised and approved all the process of study.

MMJ supported in manuscript writing.

TST supported in manuscript writing.

Acknowledgements: I thank theInternational Labor Organization Library who gave the permission to use copyrighted instrument. I would like to thank nurses working at Kigali University Hospital in Rwanda for participating in this study.

Authors' information: ${ }^{1} \mathrm{MV}, \mathrm{RN}, \mathrm{BScN}, \mathrm{MScN}$ (C) Student at University of RWANDA, College of Medicine and Health Sciences, School of Nursing and Midwifery and Risk management officer at Kigali University Teaching Hospital. ${ }^{2}$ Prof. OA, DLitt et Phil, $R N, R P N, R N E$, Training Specialist in the HRH Rwanda Program, New York University College of Nursing, School of Nursing and Midwifery,College of Medicine and Health Sciences, University of Rwanda. ${ }^{3} \mathrm{~GB}, \mathrm{RN}, \mathrm{BScN}, \mathrm{MScN}$, Assistant Lecturer at University of RWANDA, College of Medicine and the Health Sciences, School of Nursing and Midwifery. ${ }^{4} \mathrm{MJM}, \quad \mathrm{RN}, \quad \mathrm{BScN}, \quad \mathrm{MScN}, \quad \mathrm{Head}$ of Infection and Control Unit at Kigali University Teaching Hospital.

${ }^{5} \mathrm{TST}, \mathrm{RN}, \quad \mathrm{BScN}, \quad \mathrm{MScN}, \quad$ Health Services Administration Specialist, Director of Quality Managementt at Kigali University Teaching Hospital.

\section{References}

1. Hamdan M, Abu Hamra A. Workplace violence towards workers in the emergency departments of
Palestinian hospitals: a cross-sectional study. Bio Med Cent [Internet]. 2015;13(1):28. Available from: http://human-resources-

health.biomedcentral.com/articles/10.1186/s12960 -015-0018-2

2. Fute M, Mengesha ZB, Wakgari N, Tessema GA High prevalence of workplace violence among nurses working at public health facilities in Southern Ethiopia. BMC Nurs [Internet]. 2015;14(1):9. Available from:

http://bmcnurs.biomedcentral.com/articles/10.1186 /s12912-015-0062-1

3. Tiruneh BT, Bifftu BB, Tumebo AA, Kelkay MM, Anlay DZ, Dachew BA. Prevalence of workplace violence in Northwest Ethiopia: a multivariate analysis. BMC Nurs [Internet]. 2016;15(1):42. Available from: http://bmcnurs.biomedcentral.com/articles/10.1186 /s12912-016-0162-6

4. Occupational Safety and Health Administration. Guidelines for Preventing Workplace Violence for Healthcare and Social Service Workers [Internet]. 2016. 1-53 p. Available from: https://www.osha.gov/Publications/osha3148.pdf

5. Darawad MW, Al-Hussami M, Saleh AM, Mustafa WM, Odeh $\mathrm{H}$. Violence Against Nurses in Emergency Departments in Jordan. Workplace Health Saf [Internet]. 2015;63(1):9-17. Available from:

http://journals.sagepub.com/doi/10.1177/21650799 14565348

6. Xing K, Jiao M, Ma H, Qiao H, Hao Y, Li Y, et al. Physical violence against general practitioners and nurses in Chinese township hospitals: A crosssectional survey. PLoS One. 2015;10(11):1-14.

7. Al-Turki N, Afify AAM, Alateeq M. Violence against health workers in family medicine centers. $J$ Multidiscip Healthc. 2016;9(May):257-66.

8. Boafo IM, Hancock P. Workplace Violence Against Nurses. SAGE Open [Internet]. 2017;7(1):1-52. Available from:

http://journals.sagepub.com/doi/10.1177/21582440 17701187

9. Ferri P, Silvestri M, Artoni C, Di Lorenzo R. Workplace violence in different settings and among various health professionals in an Italian general hospital: A cross-sectional study. Psychol Res Behav Manag. 2016;9(September):263-75.

10. Huston CJ. Professional issue in nursing: challenges and opportunities. Lippincott. Burns CC, editor. Philadelphia: Library of Congress Cataloging-in-Publication Data; 2014. 1-431 p.

11. World Health Organisation. Joint Programme on Workplace Violence in the Health Sector questionnaire [Internet]. Human Rights. 2003. 114 p. Available from: http://www.who.int/violence_injury_prevention/viole nce/interpersonal/en/WVquestionnaire.pdf?ua $=1$

12. Sisawo EJ, Ouédraogo SYYA, Huang S-L. Workplace violence against nurses in the Gambia: mixed methods design. BMC Health Serv Res [Internet]. 2017;17(1):311. Available from: http://bmchealthservres.biomedcentral.com/articles /10.1186/s12913-017-2258-4

13. Shi L, Zhang D, Zhou C, Yang L, Sun T, Hao T, et al. A cross-sectional study on the prevalence and associated risk factors for workplace violence against Chinese nurses. BMJ Open [Internet]. 2017;7(6):e013105. Available from: http://bmjopen.bmj.com/lookup/doi/10.1136/bmjop 
en-2016-013105

14. Banda, Mayers P, Duma S. Violence against nurses in the southern region of Malawi. Heal SA Gesondheid [Internet]. 2016;21(January):415-21. Available from: http://dx.doi.org/10.1016/j.hsag.2016.01.002

15. Uzembo BAM, Butshu LHM, Gatu NRN, Alonga $\mathrm{KFM}$, Itoku ME, Irota $\mathrm{RH}$, et al. Workplace violence towards Congolese health care workers : A survey of 436 healthcare facilities in Katanga province, Democratic Republic of Congo. J Occ Heal. 2015;57(October):69-80.

16. Alameddine M, Mourad $\mathrm{Y}$, Dimassi H. A national study on nurses' exposure to occupational violence in Lebanon: Prevalence, consequences and associated factors. PLoS One. 2015;10(9):315.

17. Boafo IM, Hancock P, Gringart E. Sources, incidence and effects of non-physical workplace violence against nurses in Ghana. Nurs Open [Internet]. 2015;3(2):99-109. Available from: http://doi.wiley.com/10.1002/nop2.43

18. Di Martino V. Workplace violence in the health sector. Relationship between work stress and workplace violence in the health sector [Internet]. Vol. 1. 2003. 1-32 p. Available from: v:\%5Clbi\%5Cea\%5Cpdf\%5CEAPDF_00467.pdf\%5Cnhttp://www.ilo.org/public/engl ish/dialogue/sector/papers/health/stressviolence.pdf 